\title{
CHECKLIST OF THE CENTIPEDES (CHILOPODA) OF HISPANIOLA
}

\section{Lista anotada de los ciempiés (Chilopoda) de la Hispaniola}

\author{
Carlos A. Martínez-Muñoz ${ }^{1}$ and Daniel E. Perez-Gelabert ${ }^{2}$ \\ ${ }^{1}$ Zoological Museum, Biodiversity Unit. FIN-20014 University of Turku, Finland. Zoologisches Institut und \\ Museum, Cytologie und Evolutionsbiologie, Ernst-Moritz-Arndt-Universität Greifswald, Soldmannstrasse 23. \\ D-17487 Greifswald, Germany. biotemail@gmail.com. \\ ${ }^{2}$ Integrated Taxonomic Information System and Department of Entomology, National Museum of Natural History, \\ Smithsonian Institution. Washington, DC 20013-7012, USA. perezd@si.edu.
}

\section{ABSTRACT}

Ten years have passed since the last checklist of Hispaniolan Chilopoda was done and the last bibliographic compendium was published. In this work we expand the former list of species and bibliography, update the taxonomic classification and provide an assessment on Chilobase records. A new intensive literature review was performed and both recent and formerly overlooked myriapodological works were included. The treatment of supraspecific taxonomic ranks was updated and follows Chilobase 2.0. This catalogue lists 4 fossil taxa as well as 24 extant species of centipedes from Hispaniola, 9 of which are endemic. For each extant species considered, there is information on Hispaniolan synonymies and geographic distribution. Included are some clarifications on synonymies and locality problems, and species with uncertain taxonomic status are indicated. Chilobase 2.0 was tested for completeness and accuracy. We propose several updates, grouped by incorrect species records, records not backed by known literature and species not under their currently accepted synonym. We also recommend chilopodologists to maintain active collaboration and send their updates to this useful database.

Keywords: centipedes, Chilopoda, fauna, Hispaniola, Dominican Republic, Haiti, Chilobase, MyriaLit, EoL, MCZbase, ITIS.

\section{RESUMEN}

Han pasado 10 años desde que se publicara la última lista y compendio bibliográfico de Chilopoda de La Española. En este trabajo expandimos la lista anterior de especies y bibliografía, actualizamos la clasificación taxonómica y proveemos una evaluación de los registros en Chilobase. Se hizo una nueva revisión intensiva de la literatura y se incluyeron trabajos miriapodológicos, tanto recientes como antes obviados. El tratamiento de rangos taxonómicos supraespecíficos fue actualizado y sigue a Chilobase 2.0. Este catálogo lista cuatro táxones fósiles, así como 24 especies vivientes de ciempiés para la Hispaniola, nueve de las cuales son endémicas. Para cada especie viviente considerada hay información sobre sinonimias de la isla y distribución geográfica. Se incluyen algunas aclaraciones sobre sinonimias y problemas de localidad, y se indican las especies con estatus taxonómico incierto. Chilobase 2.0 fue evaluada en cuanto a compleción y precisión. Proponemos varias actualizaciones, agrupadas por registros de especies incorrectos, registros no respaldados por literatura y especies que no están bajo su sinónimo actual. También recomendamos a los quilopodólogos el mantener una colaboración activa y enviar sus nuevos registros a esta útil base de datos.

Palabras clave: ciempiés, Chilopoda, fauna, Hispaniola, República Dominicana, Haití, Chilobase, MyriaLit, EoL, MCZbase, ITIS. 


\section{INTRODUCTION}

The history of Hispaniolan Myriapodology started very early. The first contribution known to us is in the "Historia General de las Indias", published in 1535 by Gonzalo Fernández de Oviedo Valdés, one of the famous chroniclers of the Indies and at the time warden of the fortress of Santo Domingo city. In his narration he writes about "scolopenders or centipedes", and also about "worms", a category in which millipedes and lepidopteran larvae seem to have been mixed. Concerning the centipedes, it is evident from his story that Oviedo saw or was informed about bioluminiscent geophilomorphs and big Scolopendra specimens of about 20 centimeters or more.

More than 250 years later came the description of the "bète à mille pieds de St. Domingue" by the resident royal physician Charles Arthaud (1787). His description is detailed enough to identify the species as Scolopendra alternans Leach, 1816.

Other 50 years passed without new records, until Johann Friedrich Brandt (1840), director of the Zoological Museum of the Saint Petersburg Academy of Sciences, described Scolopendra platypus from Havana and Hispaniola. Brandt (1840) also reported Scolopendra sagraea Guérin in Gervais, 1837 from Hispaniola. The Hispaniolan specimens were collected by Benedict Jaeger, who was collector for the botanical garden in St. Petersburg and worked in the island from 1827 to 1828.

The second half of the $19^{\text {th }}$ Century was a flourishing time for Myriapodology in Europe. Scientists working on European collections started to identify, describe and name many new species, including some from the New World. One example is the species Cormocephalus impresus, described by Carl Oscar von Porat (1876) while working with material from the Natural History Museum of Gothenburg, with provenance stated as "S:t Domingo" (= Hispaniola).

The first author giving a more complete account of the Hispaniolan centipede fauna was the Danish entomologist Frederik Vilhelm August Meinert. Alexander Agassiz, the director of the Museum of Comparative Zoology (MCZ), Harvard University, sent the Chilopoda collection to Meinert, who was based at the Zoological Museum, Copenhagen. Meinert (1886) then described Cupipes ungulatus from two localities in Haiti and one in Brazil, and Otostigmus occidentalis from Haiti. He reported Scolopendra crudelis Koch, 1847 from Haiti, treated S. sagraea as its synonym and reported Scolopocryptops miersii from Haiti. In a subsequent work based on the collection at the museum in Copenhagen, Meinert (1887) published one more locality of Cupipes ungulatus and added Scolopendra alternans to the Hispaniolan fauna.

Reginald Innes Pocock was the first important reviewer of the Caribbean myriapods. Pocock (1893) listed from Hispaniola S. alternans (including S. sagraea and S. crudelis as synonyms), S. morsitans Linnaeus, 1758 (perhaps implicitly including S. platypus), Cormocephalus guildingii (including C. impressus), Cormocephalus ungulatus (as closely related to C. guildingii), Otostigmus occidentalis and Scolopocryptops ferrugineus (including Meinert's concept of $S$. miersii). That way, Hispaniola officially finished the $19^{\text {th }}$ century with six centipede species, all from order Scolopendromorpha. Karl Kraepelin (1904a) provided the first record of $S$. melanostoma Newport, 1845. Kraepelin (1904b) recorded S. alternans, and for the first time S. subspinipes. Karl Wilhelm Verhoeff (1904) described the first scutigeromorph, Pselliophora pulchritarsis. 
Ralph Vary Chamberlin (1915) worked with material deposited at the MCZ and described several Haitian species, including the first and only representative from the genus Cryptops Leach, 1814 and five species of Geophilomorpha.

Chamberlin (1918) continued working with the MCZ collection and produced a monograph on West Indian Chilopoda and Diplopoda, in which a second scutigeromorph species and two additional geophilomorphs were described. He gave the first records of Rhysida nuda (Newport, 1845), Newportia longitarsis (Newport, 1845), N. ernsti Pocock, 1891 and Mecistocephalus guildingii Newport, 1843. Additionally, he reexamined Meinert's specimens of Scolopocryptops miersii confirming them as $S$. ferrugineus, and the Haitian syntypes of $C$. ungulatus as $C$. guildingii. One hundred years have passed since Chamberlin's last work, but notably no new geophilomorph species or localities have been published.

Wolcott (1927) mentioned another name for Haiti, Scutigera forceps (Rafinesque, 1820). Chamberlin (1944) gave new localities for S. alternans, C. guildingii and Scolopocryptops melanostoma. The rest of the $20^{\text {th }}$ century passed without new scolopendromorph species from Hispaniola being described or reported. The only exceptions are two obscure records in Schileyko \& Minelli (1999) from Dominican Republic, one of Newportia cubana Chamberlin, 1915, masked as Dominica, and one of $N$. ernsti from St. Domingo (= Dominican Republic).

In the $21^{\text {st }}$ century, research on local Scolopendromorpha and Geophilomorpha revived. Shelley (2002) was the first to publish new locality records for some Hispaniolan scolopendromorphs, namely $S$. alternans and $S$. morsitans. Chao (2002) reported $R$. longipes (Newport, 1845) from Haiti. Chagas-Júnior \& Shelley (2003) included Hispaniola (both Haiti and the Dominican Republic) in the Caribbean distribution of the genus Newportia Gervais, 1847 but they did not cite species or localities.

Within his Checklist of the Hispaniolan Arthropods, Perez-Gelabert (2008) published a synthesis of Hispaniolan Chilopoda, on which 27 species names were mentioned, including synonyms. After this compilation, Perez-Gelabert \& Edgecombe (2013) updated the treatments for Scutigeromorpha and provided new records from Dominican Republic, Chagas-Júnior (2013) reported Rhysida celeris (Humbert \& Saussure, 1870) from Dominican Republic and Haiti, and Schileyko (2014) reported Newportia longitarsis stechowi from Dominican Republic. Mercurio (2016) republished former records of S. alternans from Hispaniola and added some new.

Fossil taxa from Dominican amber have been scarcely treated. Shear (1987) reported four centipede specimens, of which two were exuvii and two were adults of a species of Cryptops. Poinar (1992) cited the records by Shear (1987) and showed a photograph of an amber piece from the Costa collection, Puerto Plata, Dominican Republic, containing a specimen of house centipede, order Scutigeromorpha. Wu (1996) reported a second scutigeromorph, Scutigera coleoptrata Linnaeus, 1758, a record later questioned by Perez-Gelabert \& Edgecombe (2013). Poinar \& Poinar (1999) showed an additional amber piece containing a specimen of Scolopendromorpha, later assigned to Scolopocryptopinae by Edgecombe (2011) and Edgecombe et al. (2012). Perez-Gelabert (2008) included the fossil Cryptops sp. and the $S$. coleoptrata in his Chilopoda list. Here we synthesize the new literature and take further actions.

New sources of extant species taxa comprise genetic data and stomach content. Genetic data was found for one species, Newportia ernsti (Edgecombe et al., 2012; Vahtera et al., 2013). One record of $S$. alternans from the stomach content of a lizard (Inchaústegui et al., 1985) has been integrated. 
In the current catalog we capture pre-2008 names and publications additional to Perez-Gelabert (2008), as well as the records and bibliography from the last ten years, to produce this updated monograph. We cover 483 years of research on the Hispaniolan Chilopoda, from 1535 to the present.

\section{MATERIALS AND METHODS}

Classification from class to family ranks follows Minelli (2011), except for the date of order Geophilomorpha Pocock, which is corrected to 1896 and the date of family Geophilidae Leach, which is corrected to 1816. Presentation of families within each order starts with the "typical" family, even if the International Code of Zoological Nomenclature (ICZN, 1999) rules no rank above family level and therefore defines no term such as "type family". The rest of the families follow in alphabetical order.

Classification of genera, species and subspecies follows Chilobase 2.0 (Bonato et al., 2016), except for the correction of the publication data of two genera, one subgenus and two species, for the addition of three undetected species synonyms and for the reversal of one synonymy. Presentation of genera within families and subfamilies starts with the type genus (if recorded from Hispaniola) and continues in alphabetical order. Presentation of species within genera starts with the type species (if recorded from Hispaniola) and continues in alphabetical order. The species synonyms reported from the island are given under the valid species name, in chronological order. Deleted taxa are listed at the end of the account of their parent taxon.

This list includes the names of the genera and species in italics, authors, years of publication and one or more of the reference sources with page number in which the species is recorded from Hispaniola. Citation of dates in the text follows the ICZN (ICZN, 1999), article 22, recommendation 22A.2.2. Dates in bibliographic references follow recommendation 22A.2.3. For every species the type locality and known distribution in Hispaniola is provided. The localities given summarize all known Hispaniolan localities for the species and its synonyms. The species are classified as introduced, native or endemic.

We chose to include three theses in this compendium (Chao, 2002; Chagas-Júnior, 2003a, 2008). The theses are not publications in the sense of the Articles 8 and 9 of the Code (ICZN, 1999), so they cannot be used as a source of nomenclatural acts. However, the theses are still a valid source for descriptions, illustrations and locality records. Herewe use the mentioned thesis mainly as a source of species records (Chao, 2002), localities (Chagas-Júnior, 2003a, 2008) and also because of their (Chagas-Júnior, 2003a) explanatory power on published literature (Chagas-Júnior, 2003b). We also included the reference Chao (2008), an edited version of Chao (2002). It was commercialized by VDM Verlag, which prints "books on demand", a procedure that does not comply with article 8.1.3 of the Code (ICZN, 1999) because there is no first edition containing simultaneously obtainable copies. On the other hand, the procedure matches article 9.7 of the Code regarding that copies obtained on demand of an unpublished work (like theses) do not constitute published work. Therefore, Chao (2008) is not considered a published work in the sense of the Code.

Fossil species in Dominican amber, specimens retrieved from stomach content and records coming from molecular works are indicated in brackets. Fossils are listed separately at the beginning of the account of their parent taxon. Regarding extant genera and species, all taxonomic and geographic updates were submitted to Chilobase 2.0. Efforts were also made to correct or complete references, which were submitted to the MyriaLit Database. Comments were also sent to the Encyclopedia of Life (EoL), Integrated Taxonomic Information System (ITIS) and the Database of the Zoological Collections of the MCZ (MCZbase). 


\section{RESULTS}

This catalogue lists 4 fossil taxa as well as 24 extant species of centipedes from Hispaniola, of which 11 species occur in Dominican Republic and 21 species in Haiti. About the partition of the species, we record 8 from both Haiti and Dominican Republic, 13 only from Haiti and 3 only from Dominican Republic. There are 9 endemic species, all from Haiti. Among the remaining, 11 are native and 4 are introduced. There are no endemic chilopod genera in Hispaniola. The genera Cormocephalus, Otostigmus and extant Cryptops have not been reported from Dominican Republic and the family Scutigeridae has no records from Haiti. The order Geophilomorpha has no published occurrences from Dominican Republic and the order Lithobiomorpha is so far absent from the island. A summary of data per order is presented in Table I. The valid extant species are consolidated in Table II.

Table I. Numbers of valid extant families, genera and species, endemic species, percent of endemism and fossil species of centipedes known from Hispaniola by order.

\begin{tabular}{|c|c|c|c|c|c|c|}
\hline Orders & Families & Genera & Species & Endemic species & $\%$ Endemism & Fossil species \\
\hline Scolopendromorpha & 3 & 7 & 14 & 2 & 14.3 & 3 \\
\hline Geophilomorpha & 4 & 6 & 8 & 7 & 87.5 & 0 \\
\hline Scutigeromorpha & 2 & 2 & 2 & 0 & 0 & 1 \\
\hline TOTAL & 9 & 15 & 24 & 9 & 37.5 & 4 \\
\hline
\end{tabular}

\section{SYSTEMATIC ACCOUNT}

Class CHILOPODA Latreille, 1817

Subclass NOTOSTIGMOPHORA Verhoeff, 1901

Order SCUTIGEROMORPHA Pocock, 1895

Family SCUTIGERIDAE Leach, 1814

Dendrothereua Verhoeff, 1944

Dendrothereua linceci (Wood, 1867: 42). Perez-Gelabert \& Edgecombe, 2013: 39. Type locality: USA, Texas. Regarded as native to Hispaniola.

\section{HISPANIOLAN LOCALITIES}

DOMINICAN REPUBLIC: Nizaito, Valle Nuevo, La Vega Prov., 2,205 m; Way down from Cuevita, Valle Nuevo, La Vega Prov., 2,096 m; Hilltop on way to Palos Grandes, NE of San José de Ocoa, 1,437 m, Ocoa Prov.; Way down from Palos Grandes, NE of S. J. de Ocoa, Ocoa Prov., 1,440 m; Down from Cuevita, Valle Nuevo, La Vega Prov., 2280 m; La Jarda (monte arriba), Padre Las Casas, Azua Prov.; Caseta no. 3, Parque Nacional Sierra de Bahoruco, Independencia Prov., 1,941 m; Loma Quita Espuela, halfway to peak, 616 m, [Duarte Prov.]; Trail to peak and Centro SOECI, Pico Diego de Ocampo, Santiago Prov., 918 m; Bejucalito García, $19 \mathrm{~km} \mathrm{~W}$ of Higuey, [La Altagracia Prov.]; Palo de Agua, P. N. Sierra de Bahoruco, 1806 msnm; M. A. Pinar Parejo [Valle Nuevo, Prov. La Vega]. 


\section{DELETED GENUS}

Scutigera Lamarck, 1801

Scutigera coleoptrata Linnaeus, 1758: 638 [Fossil in Dominican amber]. - Wu, 1997: 129. Perez-Gelabert, 2008: 71. Perez-Gelabert \& Edgecombe, 2013: 42.

Scutigera coleoptrata Linnaeus, 1758: 638 [By synonymy of species below]. Perez-Gelabert, 2008: 71. Perez-Gelabert \& Edgecombe, 2013: 42. Type locality: "Hispania" (=Spain).

=Scutigera forceps (Rafinesque, 1820: 7). Muralewicz, 1910: 78. Wolcott, 1927: 12. Perez-Gelabert, 2008: 71. Type locality: "near Baltimore” (U.S.A.).

REMARKS. According to Perez-Gelabert \& Edgecombe (2013), S. coleoptrata originates in the Mediterranean region and has spread to many parts of the world by anthropogenic introduction in rather recent times. It is very unlikely that it is the species fossilized in Miocene Dominican amber. So far, extant specimens of $S$. coleoptrata have never been found in Hispaniola. The genus Scutigera and its species records are therefore deleted, the only name applicable to the records being Scutigeromorpha.

Family PSELLIODIDAE Chamberlin, 1955

Sphendononema Verhoeff, 1904

=Pselliophora Verhoeff, 1904: 259 non Pselliophora Osten-Sacken, 1886 (Diptera).

= Pselliodes Chamberlin, 1921: 25.

Sphendononema guildingii (Newport, 1845: 356). Würmli, 1978: 137. Perez-Gelabert, 2008: 71. Perez-Gelabert \& Edgecombe, 2013: 39. Type locality: Saint Vincent island. Regarded as native to Hispaniola.

\section{SYNONYMS WITH HISPANIOLAN RECORDS}

=Pselliophora pulchritarsis Verhoeff, 1904: 279. Chamberlin, 1918: 167. Würmli, 1978: 138. Perez-Gelabert, 2008: 71. Perez-Gelabert \& Edgecombe, 2013: 37. Type locality: Haiti.

=Pselliophora haitiensis Chamberlin, 1918: 170. Würmli, 1978: 138. Perez-Gelabert, 2008: 71. Perez-Gelabert \& Edgecombe, 2013: 37. Type locality: Grand Rivière.

\section{HISPANIOLAN LOCALITIES}

HAITI: Grand Rivière. DOMINICAN REPUBLIC: km 8 Cabo Rojo-Aceitillar Rd., Pedernales Prov.; Las Yayitas, Azua Prov., by river, 104 m; Las Yayitas, Azua Prov., under forest cover; El Callejón de la Loma, Parque Nacional El Choco, Puerto Plata prov., 110 m; Cerro San Francisco, Bánica, Elías Piña prov., 366 m; San Cristóbal Prov., 3 km N La Colonia, Mano Matuey, Loma Guaconejo, Prov. María Trinidad Sánchez; Loma Isabel de Torres, Puerto Plata; Prov. Independencia, La Descubierta, Isla Cabritos, 9 m. 


\section{Subclass PLEUROSTIGMOPHORA Verhoeff, 1901 \\ Order LITHOBIOMORPHA Pocock, 1895}

We have found no taxonomic papers recording lithobiomorph centipedes from Hispaniola. No Lithobiomorpha from the West Indies were listed by Pocock (1893) or Chamberlin (1918), and no current review is available. The only works on Caribbean Lithobiomorpha that we are aware of are those by Chamberlin (1952), Negrea et al. (1973) and Matic et al. (1977). Chamberlin(1952) described Lamyctes nesiotes from South Bimini, Bahamas. Negrea et al. (1973) recorded Lamyctes coeculus (Brölemann, 1889) from Cuba. Matic et al. (1977) added new Cuban localities to the distribution of $L$. coeculus and the first records of Lamyctes fulvicornis Meinert, 1868, a current synonym of Lamyctes emarginatus (Newport, 1844). The current knowledge of the group is therefore limited to two islands and three species.

Order SCOLOPENDROMORPHA Pocock, 1895

Family SCOLOPENDRIDAE Leach, 1814

Subfamily SCOLOPENDRINAE Leach, 1814

Scolopendra Linnaeus, 1758

Scolopendra morsitans Linnaeus, 1758: 638. Pocock, 1893: 459. Chamberlin, 1918: 158. Shelley, 2002: 39. Shelley et al., 2005: 45. Shelley, 2006: 5. Perez-Gelabert, 2008: 70, \& Edgecombe, 2013: 193. Type locality: Not designated. Regarded as introduced to Hispaniola.

\section{SYNONYMS WITH HISPANIOLAN RECORDS}

=Scolopendra platypus Brandt, 1840: 153. Gervais, 1847: 280. Shelley, 2006: 8. Perez-Gelabert, 2008: 70. Type locality: Havana and Hispaniola.

\section{HISPANIOLAN LOCALITIES}

Pocock (1893) wrote "Recorded from (...) ? St. Domingo by Gervais" referring to Gervais (1847) who listed S. platypus from Hispaniola. Pocock continues "The British Museum has specimens from (...) Hayti”, also meaning Hispaniola. Simaiakis \& Edgecombe (2013) refer it from Dominican Republic and Haiti. First and only definite localities in Haiti were given by Chamberlin (1918); those in Dominican Republic were given by Shelley (2002). HAITI: Jérémie; Port-au-Prince; Grande Anse; St.-Marc. DOMINICAN REPUBLIC: Azua; San Juan.

Scolopendra alternans Leach, 1816: 383. Arthaud, 1787: 427 [la bète à mille pieds de St. Domingue]. Brandt, 1840: 157. Meinert, 1886: 194. Meinert, 1887: 125. Underwood, 1887: 64. Pocock, 1893: 458. Kraepelin, 1903: 244. Kraepelin, 1904b: 318. Chamberlin, 1918: 157. Wolcott, 1927: 24 [la bête à mille pieds]. Attems, 1930: 37. Bücherl, 1942: 287. Chamberlin, 1944: 184. Bücherl, 1974: 104. Inchaústegui et al., 1985: 200 [lizard stomach content]. Lewis, 1989: 1003. Shelley, 2002: 35. Shelley, 2006: 6. Perez-Gelabert, 2008: 70. Mercurio, 2016: 12. Type locality: Not designated. Shelley (2002) selected a neotype from British Virgin Islands, Tortola, Fat Hog's Bay. Regarded as native to Hispaniola. 
REMARKS. Publication date of S. alternans corrected from 1815 (Chilobase) to 1816. The work by Leach (1816) appeared in the Transactions of the Linnean Society of London, volume 11, part 2, with 1815 as the printed date. However, it is recorded in the minute books of the society that the secretary presented part 2 to the council on January $16^{\text {th }}, 1816$, being authorized its publication, which took place on January $24^{\text {th }}, 1816$, as advertised that same day in the Times (Raphael, 1970). Kraepelin's (1904 a, b) catalogue of Paris Museum collection has been cited incorrectly at least two times, once by Shelley et al. (2005) as "Brölemann (1904)" and once by Le Bras et al. (2015) as "Kraepelin (1910)".

\section{SYNONYMS WITH HISPANIOLAN RECORDS}

=Scolopendra sagraea Guérin in Gervais, 1837: 50. Brandt, 1840: 157. Gervais, 1847: 281. Type locality: Cuba. Four specimens from Hispaniola at Saint Petersburg's museum, collected by Benedict Jaeger and reported by Brandt (1840).

=Scolopendra crudelis Koch, 1847: 170. Meinert, 1886: 194. Underwood, 1887: 64. Lewis, 2016: 24. Type locality: Saint Barthélemy island. Restored synonymy.

REMARKS. Meinert (1886) used the name S. crudelis for Hispaniolan samples. Meinert (1887) used the name $S$. alternans for other Hispaniolan samples, perhaps updating his species concept and valid name without explicitly saying it. For Pocock (1893), S. crudelis was already a synonym under S. alternans, synonymy of which Kraepelin (1903) and Chamberlin (1918) were aware of. Attems (1930) overlooked the synonymy by Pocock (1893), Kraepelin (1903) and Chamberlin (1918), Attems (1930) mistakenly introduced the character of "transverse sulcus present on tergite 1" in his description of S. crudelis. Shelley (2006) noticed the old synonymy but not the artifact by Attems (1930) and gave $S$. crudelis as a valid species. This explains why the synonymy is missing in Chilobase. Recently, Lewis (2016) reported two specimens from Hispaniola communicated by Dr. Arkady Schileyko. We confirm the synonymy, based on the original description by Koch (1847) and the re-description by Porat (1876).

\section{HISPANIOLAN LOCALITIES}

First Hispaniolan record by Brandt (1840) as $S$. sagraea. Meinert (1887) identified samples of $S$. alternans from some West Indian islands, including "St. Domingo" (= Hispaniola). Pocock(1893) wrote "Known from the following W. Indian Islands:(...) San Domingo...", therefore implying Hispaniola, but later he added "The British Museum has specimens from Hayti...", apparently also meaning Hispaniola. Attems (1930) also mentioned Haiti in the distribution, meaning Hispaniola. First Haitian definite localities were given by Meinert (1886) as $S$. crudelis and by Kraepelin (1904b) as S. alternans, first Dominican definite locality was given by Kraepelin (1904b) as S. alternans.

HAITI: Jérémie; Port-au-Prince; Diquini; Pétionville; Manneville; Grand Rivière; Momance; Cape Haitien; Christophe's Citadel; Plaisance; San Michel; Gonave I.; Lake Assuei; Etang Saumatre; Trou Caiman; Les Cayes; Borgne; Carrefour; Ennery; Pilboreau Mtn.; Thor; Vacinal Trouin. DOMINICAN REPUBLIC: Puerto Plata; Porto Cabarete; Azua; Samaná; Boca del Inferno [=Boca del Diablo], Samaná; Santo Domingo; Colegio De La Salle (Santo Domingo); East of La Romana, humid forest north of large sugar plantation. One specimen intercepted in quarantine at the District of Columbia, USA, coming from Puerto Plata. 
Scolopendra subspinipes Leach, 1816: 383. Kraepelin, 1904b: 322. Type locality: Not designated. Regarded as introduced to Hispaniola.

REMARKS. Publication date of S. subspinipes corrected from 1815 (Chilobase) to 1816, see Leach (1816) in references.

\section{HISPANIOLAN LOCALITIES}

DOMINICAN REPUBLIC: Saint-Domingue; Puerto Plata (misplaced by Kraepelin, 1904b in Brazil); Porto-Cabarete, dans un chargement de bois d'acajou (coll. H.-W. Brölemann, 1902).

\section{DELETED SPECIES}

Scolopendra gigantea Linnaeus, 1758: 638. Shelley \& Kiser, 2000: 159. Shelley, 2006: 5. Perez-Gelabert, 2008: 70. Type locality: Jamaica. Shelley \& Kiser (2000) selected a neotype from Venezuela, Carabobo, Valencia.

REMARKS. One specimen from Haiti, without further data, was found at the Zoological Museum, University of Amsterdam, The Netherlands, and assumed to represent an accidental human importation or perhaps a labeling error; the species does not appear to be established (Shelley \& Kiser, 2000).

\section{Cormocephalus Newport, 1844}

=Cupipes Kohlrausch, 1878

Cormocephalus guildingii Newport, 1845: 425. Pocock, 1893: 460. Chamberlin, 1918: 156. Chamberlin, 1944: 182. Bücherl, 1974: 100. Perez-Gelabert, 2008: 70. Type locality: Saint Vincent island. Regarded as native to Hispaniola.

REMARKS. In the species page in Chilobase it was stated "Notes: Possibly a synonym of Cormocephalus impressus Porat, 1876 according to Kraepelin (1903 - Mitt. Nat. Mus. Hamburg, 20: 181)". However, that synonymy is not to be treated as a possibility but as a certainty, and not by Kraepelin(1903) but by Pocock (1893). The opinion of Pocock is to be trusted, as he (Pocock, 1891) was the last person known to have examined the type of Cormocephalus guildingii, back in May, 1889, through the kindness of Prof. Westwood. Chamberlin (1918) followed Pocock (1893). Attems (1930) and Bücherl (1974) overlooked the records by Chamberlin (1918) but Bücherl (1974) accounted the record by Chamberlin (1944).

\section{SYNONYMS WITH HISPANIOLAN RECORDS}

=Cormocephalus impressus Porat, 1876: 15. Pocock, 1893: 460. Kraepelin, 1903: 181. Chamberlin, 1918: 156. Attems, 1930: 104. Bücherl, 1942: 298. Bücherl, 1974: 100. Schileyko, 2002: 497. Cupul-Magaña, 2009: 90. Cupul-Magaña, 2010: 4. Cruz-Trujillo et al., 2015: 308. Type locality: S:t Domingo (=Hispaniola). Restored synonymy.

REMARKS. Type locality given as "S. Domingo" (=Hispaniola) by Pocock (1893) and as Haiti (=Hispaniola) by Kraepelin (1903), Attems (1930) and Bücherl (1974). Cupul-Magaña (2009) wrongly mentions a record from "San Bartolomé (Saint Berthelemy, Haiti)" which he attributes to Porat (1876). However, Porat's record is not related to Hispaniola but refers to the island of Saint Barthelemy, a Swedish possession at the time. This mistake was not fixed by Cruz-Trujillo et al. (2015), whom again left Saint Barthelemy out of the distribution of C. impressus. Cupul-Magaña (2010) made a second mistake citing the type locality as "Dominican Republic (La Hispaniola)", instead of as "island Saint Domingo (=Hispaniola)". 
Schileyko (2002) mentioned Haiti in the distribution, without specifying that it is "island Haiti (=Hispaniola)". Kraepelin (1903) missed the synonymy by Pocock (1893). All later authors (Attems, 1930; Bücherl, 1974; Schileyko, 2002; Shelley, 2006; Cupul-Magaña, 2009, 2010; Cruz-Trujillo et al., 2015) missed the treatment by both Pocock (1893) and Chamberlin (1918). The work by Kraepelin (1903) is included in this account for the sake of completeness, but this author mistakenly introduced the character of "tooth-plates usually with three teeth" in his re-description of $C$. impressus. Number of teeth bears importance on species discrimination. Here we follow Porat's original description (8-10 teeth) and reaffirm the synonymy of C. impressus under $C$. guildingii (4+4 teeth). Synonymy is_missing in Chilobase.

=Cormocephalus ungulatus (Meinert, 1886: 187): partim major. Meinert, 1887: 123. Pocock, 1893: 460. Kraepelin, 1903: 177. Chamberlin, 1918: 156. Attems, 1930: 101. Bücherl, 1942: 300. Bücherl, 1974: 103. Perez-Gelabert, 2008: 70. Type locality: Haiti, Grande Anse, Port-au-Prince; Brazil, Pernambuco.

REMARKS. Meinert (1887) reported the third locality from Hispaniola, Haiti, Asquin (=Aquin, sic!). Pocock (1893) regarded C. ungulatus as "Related to C. guildingii". Kraepelin cited the type locality as Pernambuco [Brazil] and Haiti (=Haiti in this specific case). Chamberlin (1918) reexamined the type series and reidentified the syntypes from Grande Anse and Port-au-Prince as $C$. guildingii, leaving the syntype from Pernambuco as the only name bearer for C. ungulatus. Attems (1930) and Bücherl (1974) missed the partial synonymy of C. ungulatus to C. guildingii by Chamberlin (1918). Partial synonymy is missing in Chilobase.

\section{HISPANIOLAN LOCALITIES}

First record from Hispaniola by Porat (1876) as C. impressus, from Haiti by Meinert (1886) as C. ungulatus. HAITI: Grande Anse; Port-au-Prince; Aquin; Manneville; Pétionville; Momance; Kenscoff; Diquini; Diquini Cave.

Subfamily OTOSTIGMINAE Kraepelin, 1903

\section{Otostigmus Porat, 1876}

Otostigmus (Parotostigmus) Pocock, 1896: 25.

REMARK. Publication date of Otostigmus (Parotostigmus) corrected from 1895 (Chilobase) to 1896. The work by Pocock (1895-1896) was printed in five 8-page bundles (A. Minelli, pers. com.). The first three bundles, pages 1 to 24, were printed in December 1895, the last two bundles, pages 25 to 40, were printed in January 1896. Parotostigmus appeared in page 25, which is the first page of the fourth bundle, the first printed in 1896. A footnote dates the page as printed in January 1896.

Otostigmus (Parotostigmus) occidentalis Meinert, 1886: 185. Pocock, 1893: 461. Pocock, 1896: 25. Kraepelin, 1903: 130. Chamberlin, 1918: 155. Attems, 1930: 166. Bücherl, 1974: 115. Lewis, 1989: 1007. Shelley \& Edwards, 2004: 116. Perez-Gelabert, 2008: 70. Chagas-Júnior, 2016: 45. Type locality: Grande Anse. Regarded as endemic to Hispaniola.

REMARKS. Attems (1930) stated that he was not able to accommodate this species in his Otostigmus key due to the incompleteness of the original description. Attems (1930) cited the species but forgot to write the distribution, as he was doing for every other taxon. This explains why Bücherl (1974) listed the species with locality as "patria?". 


\section{HISPANIOLAN LOCALITIES}

HAITI: Grande Anse.

Rhysida Wood, 1862

Rhysida celeris (Humbert \& Saussure, 1870: 202) Chagas-Júnior, 2013: 19. Schileyko 2014: 183. Type locality: Carolina (U.S.A.). The type locality is clearly misassigned. Records from North America have been questioned (Shelley, 2002). Regarded as native to Hispaniola.

\section{HISPANIOLAN LOCALITIES}

HAITI: Port-au-Prince. DOMINICAN REPUBLIC: Sánchez, Bay V. Samaná.

Rhysida longipes longipes (Newport, 1845: 411). Chao, 2002: 28. Chao, 2008: 62. Waldock \& Lewis, 2014: 77. Schileyko \& Stoev, 2016: 257. Type locality: Not stated in the original publication. Regarded as introduced to Hispaniola.

REMARKS. Chao (2002) examined one specimen from "HAITI, Cape Haiti[an], March 30, 1989" from the Natural History Museum, London, UK, referring to it in his master thesis on Scolopendromorpha from Taiwan. A picture of the specimen has the identification label "Rhysida longipes Newport" and the characteristic handwriting reveals John Lewis as the author of the identification. This primary (Chao, 2002) Haitian record has not being cited in other literature known to us. Waldock \& Lewis (2014) and subsequently Schileyko \& Stoev (2016) listed the Haitian record as coming from Chao (2008), the later version of the original master thesis.

\section{HISPANIOLAN LOCALITIES}

HAITI: Cap-Haïtien.

Rhysida nuda (Newport, 1845: 412). Chamberlin, 1918: 156. Shelley \& Edwards, 2004: 116. Perez-Gelabert, 2008: 70. Type locality: Australia: New South Wales: Paramatta. Regarded as introduced to Hispaniola if truly present, but probably to be deleted.

REMARKS. Koch (1985) reviewed the taxonomy of Australian Rhysida species and determined that $R$. nuda is an endemic species of Australia; therefore all forms of Rhysida outside Australia to which the specific epithet nuda was applied belong to other species. This left in doubt the true identity of the species recorded from Haiti by Chamberlin (1918). Shelley \& Edwards (2004) also mentioned $R$. nuda from Haiti and expressed that literature records were confusing and probably unreliable. Martínez-Muñoz (2014) addressed the need to reexamine $R$. nuda specimens seen by Chamberlin (1918) before assigning them to other species. We consider that many published New World records of $R$. nuda are probably referable to either $R$. longipes or $R$. celeris.

\section{HISPANIOLAN LOCALITIES}

HAITI: Milot, Diquini. 


\title{
Family CRYPTOPIDAE Kohlrausch, 1881
}

Cryptops Leach, 1814

REMARKS. Publication date corrected from 1815 (Chilobase) to 1814, source of name also corrected, see Leach (1814) in references.

Cryptops sp. [Fossil in Dominican amber] - Shear, 1987: 43. Poinar, 1992: 92. Perez-Gelabert, 2008: 70.

Cryptops (Trigonocryptops) Verhoeff, 1906.

Cryptops (Trigonocryptops) manni Chamberlin, 1915: 501. Chamberlin, 1918: 151. Attems, 1930: 230. Bücherl, 1974: 122. Perez-Gelabert, 2008: 69. Type locality: Milot. Regarded as endemic to Hispaniola.

REMARKS. Attems (1930) subjectively assigned C. manni to subgenus Cryptops (Cryptops) Leach, 1814. However, the presence and arrangement of distal spinose processes of the ultimate pair of legs closely relate $C$. manni to the Cuban representatives of Cryptops (Trigonocryptops). Therefore, we transfer this species from subgenus Cryptops to subgenus Trigonocryptops.

\section{HISPANIOLAN LOCALITIES}

HAITI: Milot.

\author{
Family SCOLOPOCRYPTOPIDAE Pocock, 1896 \\ Subfamily SCOLOPOCRYPTOPINAE Pocock, 1896
}

Scolopocryptops Newport, 1844

=tocryptops Haase, 1887

=Dinocryptops Crabill, 1953

REMARKS. Scolopocryptops Newport, 1844 had the right author and date in Chilobase but incorrect source. It is here corrected; see Newport (1844) in references. Dinocryptops Crabill, 1953 was synonymized to Scolopocryptops by Edgecombe et al. (2012) but this synonymy is missing in Chilobase.

Scolopocryptops sp. [Fossil in Dominican amber] - Poinar \& Poinar, 1999: 82, fig. 87. Edgecombe, 2011: 359. Edgecombe et al., 2012: 769.

REMARKS. Poinar \& Poinar (1999) reconstructed the ecosystem that existed on the island of Hispaniola between fifteen and forty-five million years ago. In their work, they showed an additional amber piece containing a specimen of Scolopendromorpha. Edgecombe (2011) referred to this specimen as "a member of Scolopocryptopinae, with a single large ventral spinous process on the ultimate leg prefemur that is consistent with a more precise identity as one of the two extant genera in the Neotropics, Scolopocryptops and Dinocryptops". 
Edgecombe et al. (2012: 769) mentioned the specimen again as belonging to Scolopocryptopinae (23 leg-bearing segments and a single strong ventral spinose process on the prefemur of the last leg pair). In the same work, Edgecombe et al. (2012) synonymized Dinocryptops to Scolopocryptops, leaving the latter as the only genus within Scolopocryptopinae. Therefore, we formally assign the Dominican amber specimen to the genus Scolopocryptops.

Scolopocryptops melanostoma Newport, 1845: 406. Kraepelin, 1904a: 245. Chamberlin, 1918: 152. Chamberlin, 1944: 177. Bücherl, 1974: 129. Chagas-Júnior, 2003a: 44. Perez-Gelabert, 2008: 70 [by mistake, see remarks]. Schileyko, 2014: 154. Schileyko \& Stoev (2016): 250. Type locality: Saint Vincent island. Regarded as native to Hispaniola.

REMARKS. Hispaniolan records by Kraepelin (1904a) and Chamberlin $(1918,1944)$ have been forgotten and are absent from classic monographs (Attems, 1930; Bücherl, 1942) and from recent literature (Chagas-Júnior, 2008; Chagas-Júnior, 2010; Schileyko, 2014, Schileyko \& Stoev, 2016). A "Haiti" literature record in Chagas-Júnior (2003a), evidently coming from Bücherl (1974), was not listed in Chagas-Júnior (2008). The other recent record is found in Perez-Gelabert (2008) by reference to the work by Pocock (1893), where the species is not mentioned from Hispaniola. Bücherl (1974) was the only author noticing at least one of the historical records, specifically the record by Chamberlin (1944). Schileyko (2014) followed Chagas-Júnior (2010) and believed to be publishing the first island record: "I add to this list Dominican Republic (Island Haiti in Greater Antilles)", where Haiti means Hispaniola. Schileyko \& Stoev (2016) continued using Haiti with the same meaning of Hispaniola. Because of its importance, all localities are listed in full below.

\section{HISPANIOLAN LOCALITIES}

Kraepelin (1904a): Saint-Domingue (Sallé [leg.], 1861), meaning Hispaniola. HAITI: Chamberlin, 1918: Furcy (W. M. Mann [leg.]). Chamberlin (1944): Kenscoff, 4,500 feet, 5 [specimens], under stones, December 2, 1928 (K. P. Schmidt [leg.]). DOMINICAN REPUBLIC: Schileyko (2014): St. Cristobal, 1 spec, N 7075.

Scolopocryptops ferrugineus ferrugineus (Linnaeus, 1767: 1063). Pocock, 1893: 463. Chamberlin, 1918: 152. Bücherl, 1942: 329. Chagas-Júnior, 2003a: 26, 28. Chagas-Júnior, 2003b: 2. Chagas-Júnior, 2008: 77, 79 [as Scolopocryptops mexicana Humbert \& Saussure, 1869, but see remarks]. Perez-Gelabert, 2008: 70. Schileyko, 2014: 156. Type locality: West Africa. Regarded as native to Hispaniola.

\section{SYNONYM WITH HISPANIOLAN RECORDS}

=Scolopocryptops miersii Meinert, 1886: 181 non Newport, 1845 partim major [Haiti, Jamaica]. Kraepelin, 1903: 72. Chamberlin, 1918: 152. Attems, 1930: 261. Bücherl, 1942: 329. Chagas-Júnior, 2003a: 25; 2003b: 2; 2008: 77.

REMARKS. Proper identity of Meinert's records was subjectively established by Kraepelin (1903) and followed by Attems (1930) and Bücherl (1942). Sadly, Bücherl (1974) did not mention the issue again. The identity of Meinert's specimens was objectively established by Chamberlin (1918) who reexamined the whole series from Haiti, Jamaica and Martinique, establishing that the Haitian and Jamaican specimens were $S$. ferrugineus and that the specimens from Martinique were true $S$. miersii. At one hundred years from that time, Chamberlin's clarifications have been forgotten and it is necessary to explain the further development of this issue in the pertinent literature. 
Shelley (2000) wrote "Meinert (1886) reported it [S. miersii] from Haiti, Jamaica, and Martinique, records that surely refer to Scolopocryptops melanostomus Newport, which he considered to be a synonym". However, Shelley (2000) missed the statements by Kraepelin (1903), Attems (1930) and Bücherl (1942) regarding Meinert's records being $S$. ferrugineus, and overlooked the work by Chamberlin (1918), in which he reidentified Haitian and Jamaican records as $S$. ferrugineus and the Martinican record as true $S$. miersii. Overall, Shelley's (2000) assumption doesn't hold, as no record by Meinert (1886) is S. melanostoma. Chagas-Júnior (2003a, b, 2008) overlooked Chamberlin (1918) in his accounts of S. miersii and $S$. ferrugineus. Without knowing, he (2003 a, b) examined Meinert's MCZ specimens and independently arrived to the same conclusions than Chamberlin (1918). As Chagas-Júnior (2003a) was not able to match Meinert's specimens to his, he kept (Chagas-Júnior, 2003b) the erroneous opinion from Shelley (2000) of Meinert's records belonging to S. melanostoma. By 2005, Chagas-Júnior was certainly aware that the lot from Martinique was $S$. miersii and he was probably sure that he had seen Meinert's specimens from Haiti and Jamaica, they truly being $S$. ferrugineus. This explains why the "S. melanostoma hypothesis" and "Haiti" are not in the distribution of $S$. melanostoma in Chagas-Júnior (2008).

Chagas-Júnior (2008), in his doctoral thesis on Scolopocryptopinae, "revalidated" the name $S$. mexicana Humbert \& Saussure, 1869 for the New World species S. ferrugineus. The author correctly states that his thesis is not a publication in the sense of the Article 9 of the Code (ICZN, 1999), so it cannot be used as a source of nomenclatural acts. Martínez-Muñoz (2014) highlighted the issue and how later authors have overlooked the Code and applied the non-revalidated name $S$. mexicana to the New World forms of $S$. ferrugineus. Here we follow Martínez-Muñoz (2014) and keep S. ferrugineus.

\section{HISPANIOLAN LOCALITIES}

HAITI: Grande Anse; Jérémie; Diquini; Port-au-Prince; Pétionville; Kenscoff; Roche Plate; Formont; Macaya; La Visite. DOMINICAN REPUBLIC: La Sigua, La Vega Province; Barahona Province.

\section{DELETED SPECIES}

Scolopocryptops miersii Newport, 1845: 405. Chamberlin, 1918: 153. Perez-Gelabert, 2008: 70. Type locality: Brasilia (=Brazil). Chagas-Júnior (2003b) selected a neotype from Brazil, São Paulo, Paranapiacaba, but Chagas-Júnior (2008) claimed to have found the holotype, adding that the label reads "Paraná".

REMARKS. Chamberlin (1918) refers the species from "Haiti: Furcy (W. M. Mann)". However, this seems to be a lapsus calami, because Chamberlin also cites the same locality and collector for $S$. melanostoma immediately above of the account of $S$. miersii. There is no specimen of $S$. miersii from Furcy at the MCZ but there is a card for $S$. melanostoma and a database entry for a lost lot of the same. Therefore, the "record" of $S$. miersii from Haiti by Chamberlin (1918) is here formally deleted. Chagas-Júnior (2003a, b, 2008) overlooked Chamberlin (1918) in his account of $S$. miersii, which explains why the Haitian "record" was not mentioned by him in its distribution. 


\section{Subfamily NEWPORTIINAE Pocock, 1896}

Newportia Gervais, 1847: 298

REMARKS. Genus mentioned in Chilobase as from Gervais (1847: 243). That page does show the first mention of Newportia but it does not contain a diagnosis. The diagnosis appears on page 298, which is here used as the valid citation for the genus. The revision of Newportia by Schileyko \& Minelli appeared in volume 7, number 4 of Arthropoda Selecta. Printed date is 1998, but publication was delayed until 2.vii.1999 (A. Minelli, pers. com.).

Newportia sp. [Fossil in Dominican amber] - Wu, 1996: 126, fig. 178.

REMARKS. This record is based in a picture by Wu (1996), who regarded the specimen as a representative of Geophilomorpha. However, the picture shows a scolopendromorph with 17 antennal articles and body shape, forcipular apparatus and sternites typical of Newportia. To the best of our knowledge, this is the first literature record of fossil Newportia.

Newportia longitarsis (Newport, 1845: 407). Chamberlin, 1918: 153. Schileyko \& Minelli, 1999: 277. Perez-Gelabert, 2008: 70. Type locality: Saint Vincent island. Regarded as native to Hispaniola.

\section{HISPANIOLAN LOCALITIES}

HAITI: Pétionville, Port-au-Prince, Furcy, Manneville, Jacmel.

Newportia longitarsis stechowi Verhoeff, 1938: 123. Schileyko, 2014: 162. Type locality: Venezuela, Caracas, Maracay. Regarded as native to Hispaniola.

\section{HISPANIOLAN LOCALITIES}

DOMINICAN REPUBLIC: La Vega Province.

Newportia cubana Chamberlin, 1915: 497. Schileyko \& Minelli, 1999: 273. Type locality: Cuba: Juan Guerra, Sagua de Tánamo; Guantánamo, Arroyo Hondo. Regarded as native to Hispaniola.

REMARKS. Type locality mistaken in Chilobase, as "Cuba, Oriente, Cueva Del Fustete", evidently confused with the type locality of the Cuban synonym Newportia inexpectata Negrea, Matic \& Fundora-Martínez, 1973. The species record from Dominica by Schileyko \& Minelli (1999) is a typo, the true locality of the specimen being Dominican Republic. Arkady Schileyko (pers. com.) clarified the issue: “...exemplar No 6711 of $N$. cubana was erroneously cited by Schileyko \& Minelli (1999) as No 6709. According to my DB, specimen No 6711 is from Hispaniola Isl., Dominican Republic, Barahona Province, coffee plantation on the S edge of Polo, 1997."

REMARKS. $N$. cubana has a character combination rare in Newportia: locomotory legs with two tibial spurs and no tarsal spur. The only other Caribbean species sharing this character combination is the closely related Newportia longitarsis virginensis Lewis, 1989, while it is absent from other subspecies of $N$. longitarsis. With this unique exception, presence versus absence of leg spurs is currently used for species discrimination in Newportia. We consider these two taxa as conspecific, $N$. $l$. virginensis thus becoming the subspecies Newportia cubana virginensis Lewis, 1989. 


\section{HISPANIOLAN LOCALITIES}

DOMINICAN REPUBLIC: South edge of Polo, Barahona Province.

Newportia ernsti ernsti Pocock, 1891: 161. Chamberlin, 1918: 153. Schileyko \& Minelli, 1999: 274. Perez-Gelabert, 2008: 70. Edgecombe et al., 2012: 771 [Specimen used for sequencing]. Vahtera et al., 2013: 580 [Specimen used for sequencing]. Schileyko, 2014: 160. Type locality: Venezuela, Caracas and Brazil. Regarded as native to Hispaniola.

REMARKS. The type locality is incomplete in Chilobase and in Schileyko (2014), as "Venezuela, Caracas". It is complete in Schileyko \& Minelli (1999), as "Venezuela, Caracas and Brazil". Schileyko \& Minelli (1999) considered that a lectotype had to be selected from the two syntypes. However, this cannot be done on the base of geographic distance between localities alone. The designation has to be made with the specific purpose of clarifying the application of the species name (ICZN, 1999). As long as both syntypes are considered conspecific, there is no need for a lectotype. The species was mentioned from Haiti and St. Domingo by Schileyko \& Minelli (1999). Chagas-Júnior \& Shelley (2003) included both Haiti and the Dominican Republic in the distribution of the genus Newportia, based in the locality list by Schileyko \& Minelli (1999) (A. Chagas-Júnior, pers. com.). A. Schileyko (pers. com.) clarified that the St. Domingo distribution included in Schileyko \& Minelli (1999) was based on a lot at the Zoological Museum, Moscow University: "Newportia ernsti ernsti Pocock, 1891, No Rc 6760, 1 adult + 1 subad, Dominican Rep., La Vega Prov., $5 \mathrm{~km}$ off the Autopista Duarte, road to Jarabacoa, stn: 97 H 21, alt. 555 m, 18.03.1997, leg. Muratov \& Robinson, det. Ark.A. Schileyko".

\section{HISPANIOLAN LOCALITIES}

HAITI: Diquini, Grande Rivière, Emery, Manneville, St. Marc, Milot, Cape Haitien, Jacmel, Pétionville. DOMINICAN REPUBLIC: $5 \mathrm{~km}$ off the Autopista Duarte, road to Jarabacoa, La Vega Province.

\section{Order GEOPHILOMORPHA Pocock, 1896: 35}

REMARKS. Publication date corrected from 1895 (Minelli, 2011) to 1896. Geophilomorpha appeared in page 35 of Pocock's (1895-1896) Chilopoda, which belongs to the fifth 8-page bundle, the second printed in 1896. A footnote in page 33 gives the printing date as of January 1896. The date of 1895 has made it to the Encyclopedia of Life, harvested from Plazi.org. Plazi in turn mined the date from the Biodiversity Data Journal, which had semantically enhanced the work by Decker et al., (2014), the ultimate source.

Family GEOPHILIDAE Leach, 1816

REMARK. Publication date corrected from 1815 (Minelli, 2011) to 1816, see Leach (1816) in references.

Nesidiphilus Chamberlin, 1915

REMARKS. The genus Nesidiphilus was given in Chilobase as a synonym of Telocricus Chamberlin, 1915, supported by a reference to Kraus (1954: 295) which happened not to contain the synonymy. This issue was solved on April 2018, by returning Nesidiphilus to valid status and separating its component species from Telocricus (L. Pereira, L. Bonato and A. Minelli, pers. com.). 
Nesidiphilus juvenis Chamberlin, 1918: 161. Attems, 1929: 284. Foddai et al., 2000: 79. Perez-Gelabert, 2008: 70. Type locality: Petionville. Regarded as endemic to Hispaniola.

\section{HISPANIOLAN LOCALITIES}

HAITI: Pétionville.

Polycricus Saussure \& Humbert, 1872

$=$ Lestophilus Chamberlin, 1915

Polycricus haitiensis (Chamberlin, 1915: 526). Chamberlin, 1918: 163. Attems, 1929: 304. Foddai et al., 2000: 88. Perez-Gelabert, 2008: 70. Type locality: Furcy. Regarded as endemic to Hispaniola.

\section{HISPANIOLAN LOCALITIES}

HAITI: Furcy.

Polycricus nesiotes (Chamberlin, 1915: 527). Chamberlin, 1918: 164. Attems, 1929: 304. Foddai et al., 2000: 89. Perez-Gelabert, 2008: 70. Type locality: Petionville. Regarded as endemic to Hispaniola.

\section{HISPANIOLAN LOCALITIES}

HAITI: Pétionville.

Telocricus Chamberlin, 1915

Telocricus multipes Chamberlin, 1915: 521. Chamberlin, 1918: 162. Attems, 1929: 310. Foddai et al., 2000: 102. Perez-Gelabert, 2008: 70. Type locality: Mann[e]ville. Regarded as endemic to Hispaniola.

\section{HISPANIOLAN LOCALITIES}

HAITI: Manneville.

Family MECISTOCEPHALIDAE Bollman, 1893

Mecistocephalus Newport, 1843

Mecistocephalus guildingii Newport, 1843: 179. Chamberlin, 1918: 164. Foddai et al., 2000: 63. Perez-Gelabert, 2008: 70. Bonato et al., 2009: 28. Type locality: Saint Vincent island. Regarded as native to Hispaniola.

\section{HISPANIOLAN LOCALITIES}

HAITI: Grande Rivière. 
Family ORYIDAE Cook, 1896

Titanophilus Chamberlin, 1915

Titanophilus maximus Chamberlin, 1915: 503. Chamberlin, 1918: 160. Attems, 1929: 122. Foddai et al., 2000: 119. Perez-Gelabert, 2008: 70. Type locality: Grande Rivière. Regarded as endemic to Hispaniola.

\section{HISPANIOLAN LOCALITIES}

HAITI: Grande Rivière.

Titanophilus fratrellus Chamberlin, 1915: 505. Chamberlin, 1918: 161. Attems, 1929: 122. Foddai et al., 2000: 118. Perez-Gelabert, 2008: 70. Type locality: Petionville. Regarded as endemic to Hispaniola.

\section{HISPANIOLAN LOCALITIES}

HAITI: Pétionville.

\section{Family SCHENDYLIDAE Cook, 1896}

Ctenophilus Cook, 1896

=Pleuroschendyla Brölemann \& Ribaut, 1911

Ctenophilus nesiotes (Chamberlin, 1918: 159). Attems, 1929: 87. Pereira, 1981: 180. Pereira \& Demange, 1991: 93. Pereira \& Demange, 1997: 310. Foddai et al., 2000: 121. Perez-Gelabert, 2008: 70. Type locality: Diquini. Regarded as endemic to Hispaniola.

\section{HISPANIOLAN LOCALITIES}

HAITI: Diquini, with Jacmel also mentioned in the original description.

\section{SUMMARY OF PROPOSED UPDATES TO CHILOBASE}

Chilobase 2.0 was tested for completeness and accuracy. We found that Chilobase geographic search renders 8 species from Dominican Republic and 14 species from Haiti, of which Scolopendra alternans and Cormocephalus impressus $(=C$. guildingii) are shared, for a total of 20 Hispaniolan species records as of April, 2018. However, after adding the information available from the simple search and species pages and comparing the resulting list and records to those in our checklist, we found out that there are four incorrect species records from Dominican Republic and one from Haiti; one Hispaniolan and three Dominican records are not backed by known literature; and five species and one genus are not under their current accepted synonym. The issues found are discussed below.

\section{INCORRECT RECORDS}

The record of Paracryptops inexpectus Chamberlin, 1914 is a mismatch with a true record from Dominica (Chagas-Jr. \& Shelley, 2004). The record of Piestophilus tenuitarsis (Pocock, 1888) is a mismatch between Dominica (the type locality) and Dominican Republic. 
The record of Newportia cubana Chamberlin, 1915, is also included because a mismatch between the published record from Dominica (Schileyko \& Minelli, 1999) and Dominican Republic. However, this is a mismatch over a mistake, the record from Dominica being a misprinting for Dominican Republic, which ultimately makes the Chilobase $N$. cubana record from Dominican Republic correct. Cormocephalus impressus $(=C$. guildingii) is recorded from Haiti and Dominican Republic in Chilobase, which represents a misinterpretation of the original "S:t Domingo" (= Hispaniola) record.

\section{RECORDS NOT BACKED BY KNOWN LITERATURE}

Chilobase lists Dominican Republic in the distribution of Newportia leptotarsis Negrea, Matic \& Fundora-Martínez, 1973, but the species is not mentioned for Dominican Republic or Haiti by Schileyko \& Minelli (1999). Chilobase lists Dominican Republic in the distribution of Newportia longitarsis. However the species is not mentioned for Dominican Republic by Schileyko \& Minelli (1999) and the Dominican Republic literature record of $N$. l. virginensis that could support this distribution is not incorporated in Chilobase. A footnote on the Chilobase pages of $N$. ernsti and N. e. ernsti reads: "Records from 'Hispaniola' refer either to Haiti or the Dominican Republic". We have read Pocock (1891, 1893, 1896), Chamberlin (1918), Attems (1930) and Schileyko (2014) without finding a N. ernsti record from Hispaniola in general. The footnote seems superfluous. See also explanation on "St. Domingo" record in species' remarks. Chilobase also lists Dominican Republic in the distribution of Notiphilides maximiliani (Humbert \& Saussure, 1870). However the species is not mentioned for Dominican Republic or Haiti by Foddai et al. (2000) and there are no Hispaniolan records in the most recent species map (Calvanese \& Brescovit, 2017).

\section{RECORDS NOT UNDER THE CURRENT SYNONYM}

Scolopendra crudelis and Scolopendra cubensis are junior synonyms of Scolopendra alternans (see Pocock, 1893). Cormocephalus impressus is a junior synonym of Cormocephalus guildingii (see Pocock, 1893) but this information was absent in Chilobase. The Hispaniolan record of the former should be transferred to the latter. Two Cormocephalus ungulatus syntypes from Haiti are synonymized to Cormocephalus guildingii (see Chamberlin, 1918) but this information was absent in Chilobase. The Haitian records of the former should be transferred to the latter. Pselliophora pulchritarsis and Pselliophora haitiensis are junior synonyms of Sphendononema guildingii (see Würmli, 1978). This information was present in Chilobase but their Haitian records were not transferred to $S$. guildingii.

\section{ADDITIONAL CORRECTIONS ON GENERA}

The date of genus Cryptops Leach in Chilobase was given as 1815 . It is corrected here to 1814 and to a different publication (see Leach, 1814 in references). Scolopocryptops Newport, 1844 had the right author and date but incorrect publication and is here corrected (see Newport, 1844 in references). Dinocryptops Crabill, 1953 is a junior synonym of Scolopocryptops (see Edgecombe et al., 2012), but this information is missing in Chilobase.

Chilobase 2.0 is a free resource for the common good but it needs every author's effort to improve. We encourage colleagues dealing with centipede research to analyze their papers from the point of view of Chilobase and contribute their updates to this useful database. We actively submitted our comments to Dr. Lucio Bonato, who started to implement the necessary changes during the writing phase of this paper. 
Table II. Summary of the valid extant species of centipedes recorded from Hispaniola (Haiti and Dominican Republic). All endemic species are restricted to Haiti.

\begin{tabular}{|c|c|c|c|c|c|}
\hline Species & Haiti & $\begin{array}{c}\text { Dominican } \\
\text { Republic }\end{array}$ & Introduced & $\begin{array}{c}\text { Native } \\
\text { (non endemic) }\end{array}$ & $\begin{array}{c}\text { Hispaniola } \\
\text { Endemic }\end{array}$ \\
\hline \multicolumn{6}{|l|}{ Scutigeromorpha } \\
\hline Dendrothereua linceci (Wood, 1867) & - & $\mathrm{X}$ & - & $\mathrm{X}$ & - \\
\hline Sphendononema guildingii (Newport, 1845) & $\mathrm{X}$ & $\mathrm{X}$ & - & $\mathrm{X}$ & - \\
\hline \multicolumn{6}{|l|}{ Scolopendromorpha } \\
\hline Scolopendra alternans Leach, 1816 & $\mathrm{X}$ & $\mathrm{X}$ & - & $\mathrm{X}$ & - \\
\hline Scolopendra morsitans Linnaeus, 1758 & $\mathrm{X}$ & $\mathrm{X}$ & $\mathrm{X}$ & - & - \\
\hline Scolopendra subspinipes Leach, 1816 & - & $\mathrm{X}$ & $\mathrm{X}$ & & - \\
\hline Cormocephalus guildingii Newport, 1845 & $\mathrm{X}$ & - & - & $\mathrm{X}$ & - \\
\hline Otostigmus (Parotostigmus) occidentalis Meinert, 1886 & $\mathrm{X}$ & - & - & - & $\mathrm{X}$ \\
\hline Rhysida celeris (Humbert \& Saussure, 1870) & $\mathrm{X}$ & $\mathrm{X}$ & - & $\mathrm{X}$ & - \\
\hline Rhysida longipes longipes (Newport, 1845) & $\mathrm{X}$ & - & $\mathrm{X}$ & - & - \\
\hline Rhysida nuda (Newport, 1845) & $\mathrm{X}$ & - & $\mathrm{X}$ & - & \\
\hline Cryptops (Trigonocryptops) manni Chamberlin, 1915 & $\mathrm{X}$ & - & - & - & $\mathrm{X}$ \\
\hline Scolopocryptops ferrugineus ferrugineus (Linnaeus, 1767) & $\mathrm{X}$ & $\mathrm{X}$ & - & $\mathrm{X}$ & - \\
\hline Scolopocryptops melanostoma Newport, 1845 & $\mathrm{X}$ & $\mathrm{X}$ & - & $\mathrm{X}$ & - \\
\hline Newportia longitarsis (Newport, 1845) & $\mathrm{X}$ & $\mathrm{X}$ & - & $\mathrm{X}$ & - \\
\hline Newportia cubana Chamberlin, 1915 & - & $\mathrm{X}$ & - & $\mathrm{X}$ & - \\
\hline Newportia ernsti ernsti Pocock, 1891 & $\mathrm{X}$ & $\mathrm{X}$ & - & $\mathrm{X}$ & - \\
\hline \multicolumn{6}{|l|}{ Geophilomorpha } \\
\hline Ctenophilus nesiotes (Chamberlin, 1918) & $\mathrm{X}$ & - & - & - & $\mathrm{X}$ \\
\hline Mecistocephalus guildingii Newport, 1843 & $\mathrm{X}$ & - & - & $\mathrm{X}$ & - \\
\hline Nesidiphilus juvenis Chamberlin, 1918 & $\mathrm{X}$ & - & - & - & $\mathrm{X}$ \\
\hline Polycricus haitiensis (Chamberlin, 1915) & $\mathrm{X}$ & - & - & - & $\mathrm{X}$ \\
\hline Polycricus nesiotes (Chamberlin, 1915) & $\mathrm{X}$ & - & - & - & $\mathrm{X}$ \\
\hline Telocricus multipes Chamberlin, 1915 & $\mathrm{X}$ & - & - & - & $\mathrm{X}$ \\
\hline Titanophilus fratrellus Chamberlin, 1915 & $\mathrm{X}$ & - & - & - & $\mathrm{X}$ \\
\hline Titanophilus maximus Chamberlin, 1915 & $\mathrm{X}$ & - & - & - & $\mathrm{X}$ \\
\hline 24 species & 21 & 11 & 4 & 11 & 9 \\
\hline
\end{tabular}




\section{DISCUSSION}

It is too soon to infer diversity patterns within the island. There is a strong geographic bias, as most collections were done in Haitian territory and most species are known only from Haiti. Knowledge on the Dominican Republic's centipedes is superficial, except for Scutigeromorpha, but conversely, the scutigeromorph distribution in Haiti has not been properly researched. The zoogeographical aspects of the Neotropical Geophilomorpha, including the Haitian species, were addressed by Pereira et al. (1997) and will facilitate future analyses at Caribbean level when more data is available.

Regarding cave fauna, no information on centipedes was found in the synopsis of subterranean invertebrates of Hispaniola by Peck (1999). The only published record seems to be C. guildingii from "Diquini Cave, west of Port au Prince" by Chamberlin (1944).

At the island level, the number of species could be described as slightly low. The area of Hispaniola is more than two thirds the area of Cuba, but the number of species is just about half, 24 species (this study) versus 45 species in Cuba (Cabrera-Dávila et al., 2017). The endemicity in Hispaniola is also lower, 37.5\% (this study) versus $48.9 \%$ in Cuba (Cabrera-Dávila et al., 2017).

It should also be noted that the uniqueness of the Hispaniolan fauna is concentrated mainly in species of Geophilomorpha which, except for Ctenophilus nesiotes, have not been reviewed. Those species may enter into synonymy or have their known distribution expanded when more research in Hispaniola and the Caribbean is undertaken. On the other hand, the island as a whole remains poorly surveyed and new species records and discoveries should be expected, especially in the small-sized groups Lithobiomorpha, Geophilomorpha, Cryptops and Newportia.

\section{CONCLUSIONS}

In this work, several changes with respect to the former 2008 catalog were compiled from the literature or formalized by us. One scutigeromorph family was added (Pselliodidae). One genus was deleted (Scutigera), one genus was found to be synonym of another genus already reported from Hispaniola (Dinocryptops of Scolopocryptops), one genus was found to be a synonym of a non-reported genus (Pselliodes to Sphendononema) and one genus was added (Dendrothereua). In total, there is one genus less than in Perez-Gelabert (2008). One subgenus was added (Trigonocryptops).

Of the species names present in the 2008 catalog, two are synonyms and were transferred (S. platypus to $S$. morsitans, C. ungulatus [Haitian specimens!] to C. guildingii). Three species names and one synonym were deleted (Scolopendra gigantea, Scolopocryptops miersii, Scutigera coleoptrata and Scutigera forceps). Those names can be listed in future compendia for completeness but should not be cited in listings of extant species.

Eight species names and one subspecies name were added. From the eight species names, five are valid and represent a $25 \%$ increase in the valid species count from the previous list. The other three new species names are previously undetected synonyms.

The description of new species from Hispaniola encompasses a 78-year interval, from 1840 to 1918. Its maximum of 8 new described species occurred during 1915-1918 and then stopped. In the last 100 years no new species have been described from the island, which combined with the insufficient geographic coverage highlights the incomplete knowledge of the group. 


\section{RECOMMENDATIONS}

After this comprehensive review, several priority tasks are due. It is recommended to assign secondary georeferences to legacy data in order to map the known species diversity. Museum specimens in the island and overseas should be located and examined to continue filling taxonomic and geographic gaps. From the point of view of conservation, endemic species should be evaluated according to the IUCN Red List criteria, considering that they were all reported from Haiti, where extensive habitat loss has occurred. New samplings should be undertaken, including fragile ecosystems like montane forests and caves. Ultimately, morphological and molecular studies are required to understand the origin and affinities of the Hispaniolan centipede fauna.

\section{ACKNOWLEDGEMENTS}

A Smithsonian Graduate Student Fellowship to C. Martínez allowed both authors to meet in Washington DC and agree further collaboration. This research was funded by an EDUFI Fellowship to C. Martínez. Several colleagues have kindly shared information, recommendations and literature (Lucio Bonato, Alessandro Minelli, Luis Alberto Pereira, Greg Edgecombe, Jui-Lung Chao, Arkady Schileyko and Amazonas Chagas-Júnior). Special thanks to Lucio Bonato for updating the Chilobase. Dr. Darren J. Mann kindly provided pictures of the holotype of Cormocephalus guildingii. We also thank the reviewers that helped us improve the manuscript.

\section{LITERATURE CITED}

Arthaud, C. 1787. Description de la bète à mille pieds de St. Domingue. Observations et Mémoires sur la Physique, sur l'Histoire Naturelle et sur les Arts et Métiers, 30 (1): 427-428.

Attems, C. 1929. Myriapoda. 1. Geophilomorpha. Das Tierreich, 52: xxiii +388 pp.

Attems, C. 1930. Myriapoda. 2. Scolopendromorpha. Das Tierreich, 54: xix + 308 pp.

Bonato, L., F. G. Cupul-Magaña and A. Minelli. 2009. Mecistocephalus guildingii Newport, 1843, a tropical centipede with amphi-Atlantic distribution (Chilopoda: Geophilomorpha). Zootaxa, 2271: 27-42.

Bonato, L., A. Chagas-Júnior, G. D. Edgecombe, J. G. E. Lewis, A. Minelli, L. A. Pereira, R. M. Shelley, P. Stoev and M. Zapparoli. 2016. ChiloBase 2.0 - A World Catalogue of Centipedes (Chilopoda). http://chilobase.biologia.unipd.it. [Accessed April 2018].

Brandt, J. F. 1840. Observations sur les espèces qui composent le genre Scolopendra, suivies des caractères des espèces qui se trouvent dans le Muséum zoologique de l'Académie des Sciences de St. Pétersbourg, et de quelques coups d'oeil sur leur distribution géographique. Bulletin scientifique publié par l'Académie Impériale des Sciences de Saint-Pétersbourg, 7 (11): 147-160.

Bücherl, W. 1942. Catálogo dos Quilópodos da zona neotrópica. Memórias do Instituto Butantan, 15: 251-372.

Bücherl, W. 1974. Die Scolopendromorpha der Neotropischen Region. Symposia of the Zoological Society of London, 32: 99-133. 
Cabrera Dávila, G., A. A. Socarrás, E. Gutiérrez Cubría, T. Tcherva, C. A. Martínez-Muñoz and A. Lozada Piña. 2017. Fauna del suelo. pp. 254-283. In: Diversidad biológica de Cuba: métodos de inventario, monitoreo y colecciones biológicas (C.A. Mancina \& D. D. Cruz, eds.). Editorial AMA, La Habana, 502 pp.

Calvanese, V. C. and A. D. Brescovit. 2017. A new species of Notiphilides from Amazonia, with a redescription of $\mathrm{N}$. grandis (Chilopoda, Geophilomorpha, Oryidae). Zootaxa, 4232 (1): 1-20.

Chagas-Júnior, A. 2003a. Revisão das espécies neotropicais de Scolopocryptopinae (Chilopoda: Scolopendromorpha: Scolopocryptopidae). Dissertation presented in partial fulfillment of the requirements for the degree of Master of Biological Sciences - Zoology. Museu Nacional, Universidade Federal do Rio de Janeiro, Rio de Janeiro, Brasil. xii + 79 pp.

Chagas-Júnior, A. 2003b. The Neotropical taxa of the genus Dinocryptops Crabill, 1953 (Chilopoda: Scolopendromorpha), Zootaxa, 237: 1-11.

Chagas-Júnior, A. 2008. Revisão sistemática e análise filogenética dos Scolopocryptopinae (Chilopoda, Scolopendromorpha). Dissertation presented in partial fulfillment of the requirements for the degree of Doctor of Biological Sciences - Zoology. Museu Nacional, Universidade Federal do Rio de Janeiro, Rio de Janeiro, Brasil. xxi +218 pp.

Chagas-Júnior, A. 2010. On Scolopocryptops species from the Fiji Islands (Chilopoda, Scolopendromorpha, Scolopocryptopidae). International Journal of Myriapodology, 3: 159-168.

Chagas-Júnior, A. 2013. A redescription of Rhysida celeris (Humbert \& Saussure, 1870), with a proposal of eight new synonyms (Scolopendromorpha, Scolopendridae, Otostigminae). ZooKeys, 258: 17-29.

Chagas-Júnior, A. 2016. A systematic appraisal of the types of ten species of Otostigmus (Parotostigmus) (Scolopendromorpha, Scolopendridae, Otostigminae). Zootaxa, 147 (1): 36-58.

Chagas-Júnior, A. and R. M. Shelley. 2003. The centipede genus Newportia Gervais, 1847, in Mexico: description of a new troglomorphic species; redescription of $N$. sabina Chamberlin, 1942; revival of N. azteca Humbert \& Saussure, 1869; and a summary of the fauna (Scolopendromorpha: Scolopocryptopidae: Newportiinae). Zootaxa, 379: 1-20.

Chagas-Júnior, A. and R. M. Shelley. 2004. Rediscovery and redescription of the centipede Paracryptops inexpectus Chamberlin, 1914, with an account of the genus (Scolopendromorpha: Cryptopidae: Cryptopinae). Zootaxa, 475: 1-8.

Chamberlin, R. V. 1915. New chilopods from Mexico and the West Indies. Bulletin of the Museum of Comparative Zoology, 59 (8): 493-541 + 5 pls.

Chamberlin, R. V. 1918. The Chilopoda and Diplopoda of the West Indies. Bulletin of the Museum of Comparative Zoology, 62 (5): 150-262.

Chamberlin, R. V. 1921. Results of the Bryant Walker expeditions of the University of Michigan to Columbia 1913 and British Guiana 1914. Occasional Papers of the Museum of Zoology, University of Michigan, 97: 1-28. 
Chamberlin, R. V. 1944. Chilopods in the collections of Field Museum of Natural History. Field Museum Natural History, Zoological Series, 28 (4): 175-216 + plates 13-17.

Chamberlin, R. V. 1952. The centipeds (Chilopoda) of South Bimini, Bahama Islands, British West Indies. American Museum Novitates, 1576: 1-8.

Chao, J.-L. 2002. Revision on Scolopendromorpha (Chilopoda) from Taiwan. Master Thesis, Sun Yat-Sen University Taiwan, vi + 98 pp.

Chao, J.-L. 2008. Scolopendromorpha (Chilopoda) of Taiwan. VDM Verlag Dr. Müller, Saarbrücken, 94 pp.

Cruz-Trujillo, L. E., F. G. Cupul-Magaña and R. Mireles-Merchant. 2015. Primer registro del ciempiés Cormocephalus impressus Porat, 1876 (Scolopendromorpha: Scolopendridae) de Morelos, México. Boletín de la Sociedad Entomológica Aragonesa, 56: 308.

Cupul-Magaña, F. G. 2009. Redescubrimiento de Cormocephalus impressus (Chilopoda: Scolopendromorpha: Scolopendridae) para México. BIOCYT, 2 (8): 48-54.

Cupul-Magaña, F. G. 2010. An annotated list of the centipedes (Chilopoda) in the National Collection of Arachnids, Instituto de Biología, Universidad Nacional Autónoma de México. Insecta Mundi, 0125: 1-10.

Decker, P., H. S. Reip and K. Voigtländer. 2014. Millipedes and centipedes in German greenhouses (Myriapoda: Diplopoda, Chilopoda). Biodiversity Data Journal, 2, e1066: 1-43.

Edgecombe, G. D. 2011. Chilopoda - Fossil history: 355-361. In: Minelli, A. (ed.): Treatise on Zoology - Anatomy, Taxonomy, Biology. The Myriapoda, Volume 1. Brill, Leiden, 530 pp.

Edgecombe, G. D., V. Vahtera, S. R. Stock, A. Kallonen, X. Xiao, A. Rack and G. Giribet. 2012. A scolopocryptopid centipede (Chilopoda: Scolopendromorpha) from Mexican amber: synchrotron microtomography and phylogenetic placement using a combined morphological and molecular data set. Zoological Journal of the Linnean Society, 166: 768-786.

Fernández de Oviedo Valdés, G. 1535. Historia General y Natural delas Indias, Yslas y Tierra Firme del Mar Océano. Imprenta de Juan Cromberger, Sevilla, 193 double-sided folia.

Foddai, D., L. A. Pereira and A. Minelli. 2000. A catalogue of the geophilomorph centipedes (Chilopoda) from Central and South America including Mexico. Amazoniana, 16: 59-185.

Gervais, P. 1847. Classe II. Chilopodes. 210-328. In: Walckenaer, O. A. Baron de and P. Gervais. Histoire naturelle des Insectes. Aptères. Tome Quatrième. Imprimerie de Fain et Thunot, Paris, xvi + 623 pp.

Humbert, A. and H. de Saussure. 1870. Myriapoda nova Americana (series 2a). Description de divers Myriapodes nouveaux de musée de Vienne. Ordo Chilopoda. Revue et Magasin de Zoologie, $2^{\mathrm{e}}$ série, 22: 202-205.

ICZN. 1999. International Code of Zoological Nomenclature. Fourth Edition. The International Trust for Zoological Nomenclature, London, UK. 306 pp. 
Inchaústegui, S. J., A. Schwartz and R. W. Henderson. 1985. Hispaniolan giant Diploglossus (Sauria: Anguidae): description of a new species and notes on the ecology of D. warreni. Amphibia-Reptilia, 6: 195-201.

Koch, C. L. 1847. System der Myriapoden, mit den Verzeichnissen und Berichtigungen zu Deutschlands Crustaceen, Myriapoden und Arachniden. In: Panzer, G. W. F. and G. A. W. Herrich-Schäffer (Eds.): Kritische Revision der Insectenfaune Deutschlands, III. Bändchen. F. Pustet, Regensburg: 1-196.

Koch, L. E. 1985. The taxonomy of the Australian centipedes of the genus Rhysida Wood (Chilopoda: Scolopendridae: Otostigminae). Journal of Natural History, 19: 205-214.

Kraepelin, K. 1903. Revision der Scolopendriden. Mitteilungen aus dem Naturhistorischen Museum in Hamburg, 20: 1-276.

Kraepelin, K. 1904a. Catalogue des scolopendrides des collections du Muséum d'Histoire naturelle de Paris. (Collection du Muséum déterminée par M. le professeur Karl Kraepelin, et collection H. W. Brölemann). Première partie. - Scolopendrides en dehors du genre Scolopendra. Bulletin du Muséum d'Histoire Naturelle, 10 (5): 243-253.

Kraepelin, K. 1904b. Catalogue des scolopendrides des collections du Muséum d'Histoire Naturelle de Paris, (Collection du Muséum déterminée par M. le professeur Karl Kraepelin, et collection H. W. Brölemann). Deuxième partie. - Genre Scolopendra. Bulletin du Muséum d'Histoire Naturelle, 10 (6): 316-325.

Kraus, O. 1954. Myriapoden aus El Salvador. Senckenbergiana Biologica, 35: 293-349.

Le Bras, G., J.-J. Geoffroy, L. Albenga and J.-P. Mauriès. 2015. The Myriapoda and Onychophora collection (MY) of the Muséum national d'Histoire naturelle (MNHN, Paris). ZooKeys, 518: 139-153.

Leach, W. E. 1814. Crustaceology. In: Brewster's Edinburgh Encyclopaedia, 7 (2): 383-437 + plate 221 .

Leach, W. E. 1816 [1815]. A tabular view of the external characters of four classes of animals, which Linné arranged under Insecta; with the distribution of the genera composing three of these classes into orders, etc. and descriptions of several new genera and species. Transactions of the Linnean Society of London, 11 (2): 306-400.

Lewis, J. G. E. 1989. The scolopendromorph centipedes of St. John, U.S. Virgin Islands collected by Dr. W. B. Muchmore. Journal of Natural History, 23 (5): 1003-1016.

Lewis, J. G. E. 2016. On the consistency of some taxonomic characters in the Scolopendromorpha and comments on the scolopocryptopid subfamily Kethopinae (Myriapoda: Chilopoda). Acta Societatis Zoologicae Bohemicae, 80: 21-31.

Martínez-Muñoz, C. A. 2014. El despertar de los gigantes: Revisión taxonómica preliminar de los ciempiés escolopendromorfos (Chilopoda: Scolopendromorpha) de la República de Cuba. Boletín de la Sociedad Entomológica Aragonesa, 55: 185-192.

Matic, Z., S. Negrea and C. Fundora Martínez. 1977. Recherches sur les Chilopodes hypogés de Cuba. II. pp. 277-301. In: Résultats des expéditions biospéologiques cubanoroumaines à Cuba, II. Ed. Academiei, Bucureşti. 420 pp. 
Meinert, F. 1886. Myriapoda Musei Cantabrigensis, Mass. Part I. Chilopoda. Proceedings of the American Philosophical Society, 23 (122): 161-233.

Meinert, F. 1887. Myriapoda Musei Hauniensis. Part III. Chilopoda. Vindenskabelige Meddelelser fra den naturhistoriske Forening Kjöbenhavn 1884-1886, 47: 100-150.

Mercurio, R. J. 2016. Resurrection of Scolopendra longipes Wood and Scolopendra cubensis Saussure from synonymy with Scolopendraalternans Leach(Chilopoda, Scolopendromorpha, Scolopendridae): an enigmatic species-group needing phylogeographic analysis, with an overview on the origin and distribution of centipedes in the Caribbean region. Zootaxa, 4111 (1): 1-20.

Minelli, A. 2011. Class Chilopoda, Class Symphyla and Class Pauropoda. (pp. 157-158). In: Zhang, Z.-Q. (Ed.). Animal biodiversity: An outline of higher-level classification and survey of taxonomic richness. Zootaxa, 3148: 1-237.

Muralewicz, W. S. 1910. Uebersicht über die Myriopoden-Fauna des Kaukasus. Teil I. 1. Literatur 2. Chilopoda. Mitteilungen des Kaukasischen Museums-Izvěstija Kavkazskago Muzeja, 5 (1): 1-80.

Negrea, S., Z. Matic and C. Fundora Martínez. 1973. Recherches sur les Chilopodes hypogés de Cuba. I. pp. 233-239. In: Résultats des expéditions biospéologiques cubanoroumaines à Cuba, I. Ed. Academiei. Bucureşti. 424 pp.

Newport, G. 1843. On some new genera of the class Myriapoda. Proceedings of the Zoological Society of London, 10 (1842): 177-181.

Newport, G. 1844. Monograph of the class Myriapoda, Order Chilopoda; with observations on the general arrangement of the Articulata. Part I. Transactions of the Linnean Society of London, 19 (3): 265-302 + plate 33.

Newport, G. 1845. Monograph of the class Myriapoda, Order Chilopoda; with observations on the general arrangement of the Articulata. Part II. Transactions of the Linnean Society of London, 19 (4): 349-439 + plate 40.

Peck, S. B. 1999. Synopsis of diversity of subterranean invertebrate faunas of the West Indian island of Hispaniola. Novitates Caribaea, 1: 14-32.

Pereira, L. A. 1981. Estudios sobre geofilomorfos neotropicales. II. Nuevos aportes al conocimiento de Ctenophilus nesiotes (Chamberlin, 1918). Neotropica, 27179-184.

Pereira, L. A. and J.-M. Démange. 1991. Sur les espèces du genre Ctenophilus Cook, 1896 (Chilopoda, Geophilomorpha, Schendylidae). Bulletin du Muséum national d'Histoire naturelle, Paris, série 4, A 13 (1-2): 81-96.

Pereira, L. A. and J.-M. Démange. 1997. Nouvelle contribution à la connaissance du genre Ctenophilus Cook, 1896, à répartition géographique disjointe (Myriapoda, Chilopoda, Geophilomorpha, Schendylidae). Zoosystema, 19: 293-326.

Pereira, L. A., D. Foddai and A. Minelli. 1997. Zoogeographical aspects of Neotropical Geophilomorpha (Chilopoda). Entomologica Scandinavica Supplement, 51: 77-86. 
Perez-Gelabert, D. E. 2008. Arthropods of Hispaniola (Dominican Republic and Haiti): a checklist and bibliography. Zootaxa, 1831: 1-530.

Perez-Gelabert, D. E. and G. D. Edgecombe. 2013. Scutigeromorph centipedes (Chilopoda: Scutigeromorpha) of the Dominican Republic, Hispaniola. Novitates Caribaea, 6: 36-44.

Pocock, R. I. 1891. Notes on the synonymy of some species of Scolopendridae with description of new genera and species of the group. Annals and Magazine of Natural History, sixth series, 7 (37): 51-68.

Pocock, R. I. 1893. Contributions to our knowledge of the arthropod fauna of the West Indies. Part II. Chilopoda. Journal of the Linnean Society of London (Zoology), 24: 454-473.

Pocock, R. I. 1895-1896. Chilopoda. Biologia Centrali-Americana, 1: 1-40.

Poinar, G. O., Jr. 1992. Life in Amber. Stanford University Press, Stanford, 350 pp.

Poinar, G. O. Jr. and R. Poinar. 1999. The Amber Forest. A Reconstruction of a Vanished World. Princeton, NJ: Princeton University Press, xviii + 239 pp.

Porat, C. O. von. 1876. Om några exotiska Myriopoder. Bihang till Kongliga Svenska VetenskapsAkademien Handligar, 4 (7): 1-48.

Raphael, S. 1970. The publication dates of the Transactions of the Linnean Society of London, Series I, 1791-1875. Biological Journal of the Linnean Society, 2: 61-76.

Schileyko, A. A. 2002. Scolopendromorpha. pp. 479-500. In: J. Adis (ed.), Amazonian Arachnida and Myriapoda: identification keys to all classes, orders, families, some genera, and lists of known terrestrial species. Pensoft Publishers; Sofia-Moscow. 590 pp.

Schileyko, A. A. 2014. A contribution to the centipede fauna of Venezuela (Chilopoda: Scolopendromorpha). Zootaxa, 3821 (2): 151-192.

Schileyko, A. [A.] and A. Minelli. 1999 [1998]. On the genus Newportia Gervais, 1847 (Chilopoda: Scolopendromorpha: Newportiidae). Arthropoda Selecta, 7 (4): 265-299.

Schileyko, A. A. and P. E. Stoev. 2016. Scolopendromorpha of New Guinea and adjacent islands (Myriapoda, Chilopoda). Zootaxa, 4147 (3): 247-280.

Shear, W. A. 1987. Myriapod fossils from the Dominican Amber. In: Minelli, A. (ed.). 7th International Congress of Myriapodology. Abstracts of the Lectures: 43.

Shelley, R. M. 2000. Occurrence of the centipede, Dinocryptops miersii (Newport) (Scolopendromorpha: Scolopocryptopidae), in Tobago, Trinidad and Tobago. Caribbean Journal of Science, 36 (1-2): 155-156.

Shelley, R. M. 2002. A synopsis of the North American centipedes of the order Scolopendromorpha (Chilopoda). Virginia Museum of Natural History Memoir, 5: 1-105.

Shelley, R. M. 2006. A chronological catalog of the New World species of Scolopendra L., 1758 (Chilopoda: Scolopendromorpha: Scolopendridae). Zootaxa, 1253: 1-50. 
Shelley, R. M. and G. B. Edwards. 2004. A fourth Floridian record of the centipede genus Rhysida Wood, 1862; potential establishment of $R$. l. longipes (Newport, 1845) in MiamiDade County (Scolopendromorpha: Scolopendridae: Otostigminae). Entomological News, 115 (2): 116-119.

Shelley, R. M. and S. B. Kiser. 2000. Neotype designation and a diagnostic account for the centipede, Scolopendra gigantea L. 1758, with an account of S. galapagoensis Bollman 1889 (Chilopoda Scolopendromorpha Scolopendridae). Tropical Zoology, 13 (1): 159-170.

Shelley, R. M., G. B. Edwards and A. Chagas-Júnior. 2005. Introduction of the centipede Scolopendra morsitans L., 1758, into northeastern Florida, the first authentic North American record, with a review of its global occurrences (Scolopendromorpha: Scolopendridae: Scolopendrinae). Entomological News, 116 (1): 39-58.

Simaiakis, S. M. and G. D. Edgecombe. 2013. Scolopendromorph centipedes (Chilopoda: Scolopendromorpha) in the Natural History Museum (London): A review of the hitherto unidentified species collected in Africa, with remarks on taxonomy and distribution, and a new species of Otostigmus (Parotostigmus). Zootaxa, 3734 (2): 169-198.

Underwood, L. M. 1887. The Scolopendridae of the United States. Entomologica Americana, 3 (4): 61-65.

Vahtera, V., G. D. Edgecombe and G. Giribet. 2013. Phylogenetics of scolopendromorph centipedes: can denser taxon sampling improve an artificial classification? Invertebrate Systematics, 27 (5): 578-602.

Verhoeff, C. W. 1904. Über Gattungen der Spinnenasseln (Scutigeriden). Sitzungsberichte der Gesellschaft naturforschender Freunde zu Berlin, [1904]: 245-285.

Waldock, J. M. and J. G. E. Lewis. 2014. Recent collections of centipedes from Christmas Island (Myriapoda: Chilopoda). Raffles Bulletin of Zoology, 30: 71-80.

Wolcott, G. N. 1927. Entomologie d'Haiti. Service Technique du Departement de l'Agriculture, Port-au-Prince, 440 pp.

Wu, R. J. C. 1996. Secrets of a Lost World: Dominican amber and its Inclusions. Privately published, Santo Domingo, $222 \mathrm{pp}$.

Würmli, M. 1978. Synopsis der neotropischen Pselliodidae (Chilopoda: Scutigeromorpha). Studies on Neotropical Fauna and Environment, 13: 135-142.

[Recibido: 07 de mayo, 2018. Aceptado para publicación: 06 de junio, 2018] 